\title{
SPATIAL, SEASONAL, AND TEMPORAL VARIATIONS IN RAINFALL AGGRESSIVENESS IN THE SOUTH OF BRAZIL
}

\author{
Álvaro J. Back ${ }^{1 *}$, Fabiane N. Gonçalves² ${ }^{2}$ Fernando M. Fan ${ }^{3}$ \\ ${ }^{1 *}$ Corresponding author. Empresa de Pesquisa Agropecuária e Extensão Rural de Santa Catarina/ Urussanga - SC, Brasil. \\ E-mail: ajb@epagri.sc.gov.br | ORCID ID: http://orcid.org/0000-0002-0057-2186
}

\section{KEYWORDS}

erosivity, soil conservation, precipitation, climatic trends.

\begin{abstract}
The objective of this study is to evaluate spatial and temporal variations in rainfall aggressiveness in southern Brazil. A total of 181 rain gauge stations located in southern Brazil with rainfall time series from 1976 to 2015 were used. Seasonal and annual rainfall aggressiveness values measured according to the Modified Fournier Index (MFI) were analyzed. The trends in the data series were evaluated using the Mann-Kendall test at a level of significance of 5\%. Maps on spatial and seasonal variations in rainfall aggressiveness were prepared. The percentage of rain gauge stations with significant decreasing trends, significant increasing trends, and no significant trends in rainfall aggressiveness between years was $3.3 \%, 7.7 \%$, and $89.0 \%$, respectively. Moreover, $90 \%$ of stations had no significant trends between seasons. There were seasonal differences in rainfall aggressiveness between the three southern states in Brazil caused by rainfall factors. Rainfall aggressiveness was comparatively higher in the west of Santa Catarina and southwest of Paraná due to the rains originating from the mesoscale convective systems predominant in autumn, and in the north coast of Santa Catarina and east coast of Paraná due to convective and orographic precipitations predominant in the summer.
\end{abstract}

\section{INTRODUCTION}

Increased soil erosion is recognized as a significant environmental problem, causing soil loss, degradation of productive areas, and damage to urban areas. In Brazil, soil degradation is caused primarily by poor soil management and use, presence of fragile soils, and a pluviometric regime characterized by heavy rainfall, leading to water erosion.

Experimental research on water erosion is essential for conserving soil and water quality. However, obtaining representative water erosion values is expensive, laborintensive, and time-consuming (Anache et al., 2017). Modeling is a technique widely used in water erosion studies and allows performing simulations using different scenarios and obtaining rapid responses compared to experimental research. In this respect, several mathematical models were developed to estimate soil loss due to erosion, including the Universal Soil Loss Equation (USLE), which estimates rainfall erosivity (RE) using the RE index.

The RE index expresses the capacity of rainfall to cause erosion in an unprotected area from a specific geographical region (FAO, 1967). This index is determined by several factors, including rainfall droplet size distribution, falling raindrop velocity, raindrop quantity, drop momentum and kinetic energy, as well as rainfall intensity, duration, and frequency. The most commonly used RE indices are EI30 (Wischmeier \& Smith, 1960) and KE >25 (Hudson, 1973), and are measured by analyzing pluviographic data.

According to Lai (1990), RE is defined as the aggressiveness of rainfall as an erosive agent. The term rain aggressiveness was used as an indication of the degree of rainfall erosivity; however, it should not be confused with the erosivity index used in USLE.

In the evaluation of erosivity indices, it is critical to analyze rainfall data series with less than an hourly time resolution. However, these data are scarce in Brazil and other countries (Waltrick et al., 2015; Sadeghi et al., 2017). In view of the difficulty of obtaining data for calculating the $\mathrm{RE}$ index, RE has been estimated using indices based on total monthly rainfall, especially the Fournier Index and MFI (Jordán \& Bellinfante, 2000; Lujan \& Gabriels, 2005; Tafur \& Moncayo, 2010; De Luis et al., 2010; Oliveira et al., 2012; Yin et al., 2015; Essel et al., 2016).

${ }^{2}$ Universidade do Extremo Sul Catarinense/ Criciúma - SC, Brasil.

${ }^{3}$ Universidade Federal do Rio Grande do Sul/ Porto Alegre - RS, Brasil.

Received in: 5-2-2018

Accepted in: 6-3-2019 
Vega \& Flebes (2007) have pointed out that rainfall aggressiveness is related with rainfall kinetic energy, which, although little discussed in meteorology and climatology, is fundamental in agricultural and forestry sciences because of its substantial contribution to soil degradation. The knowledge of rainfall aggressiveness in a region allows its sustainable use to perform zoning of different areas according to their erosive potential and plan the appropriate use of the soil according to the risk of erosion (Ramirez-Oritz et al., 2007). The advantages of calculating MFI are the ease of obtaining large monthly rainfall data series and, consequently, spatially represent its variation and the strong correlation between MFI and RE. Furthermore, the knowledge of seasonal and spatial variations in rainfall aggressiveness is crucial for decision-making and implementation of preventive and erosion control measures (Hazbavi \& Sadeghi, 2016; Davudirad et al., 2016).

The presence of significant changes in rainfall indicates the need to change the size patterns of water infrastructures. The growing trend in rainfall aggressiveness may indicate an increase in erosion problems and the need to revise and update RE indices and maps as well as maps of soil loss and erosion hazard potential according to USLE guidelines.
The objective of this study is to evaluate spatial and temporal variations in rainfall aggressiveness in the south of Brazil. This analysis is fundamental for elaborating maps of soil loss potential and assess the increase in sediment production in watersheds. The present study intends to answer the following questions: (i) Is it necessary to update erosion studies as a function of trends in rainfall?" And (ii) Is it possible to attribute increases or decreases in sediment production to a decrease in rainfall aggressiveness?

\section{MATERIAL AND METHODS}

Daily precipitation data series collected in 181 rain gauge stations from the National Water Agency (Agência Nacional de Águas-ANA) were used. Of these, 70 stations are in the state of Paraná, 62 in the state of Santa Catarina, and 49 in the state of Rio Grande do Sul (Figure 1). Stations with more than 32 years of annual data series for the period 1976-2015 were selected. Missed data on total monthly rainfall in these stations were filled using the regional weighting method based on data from three nearby stations according to the methodology proposed by Tucci (2015).

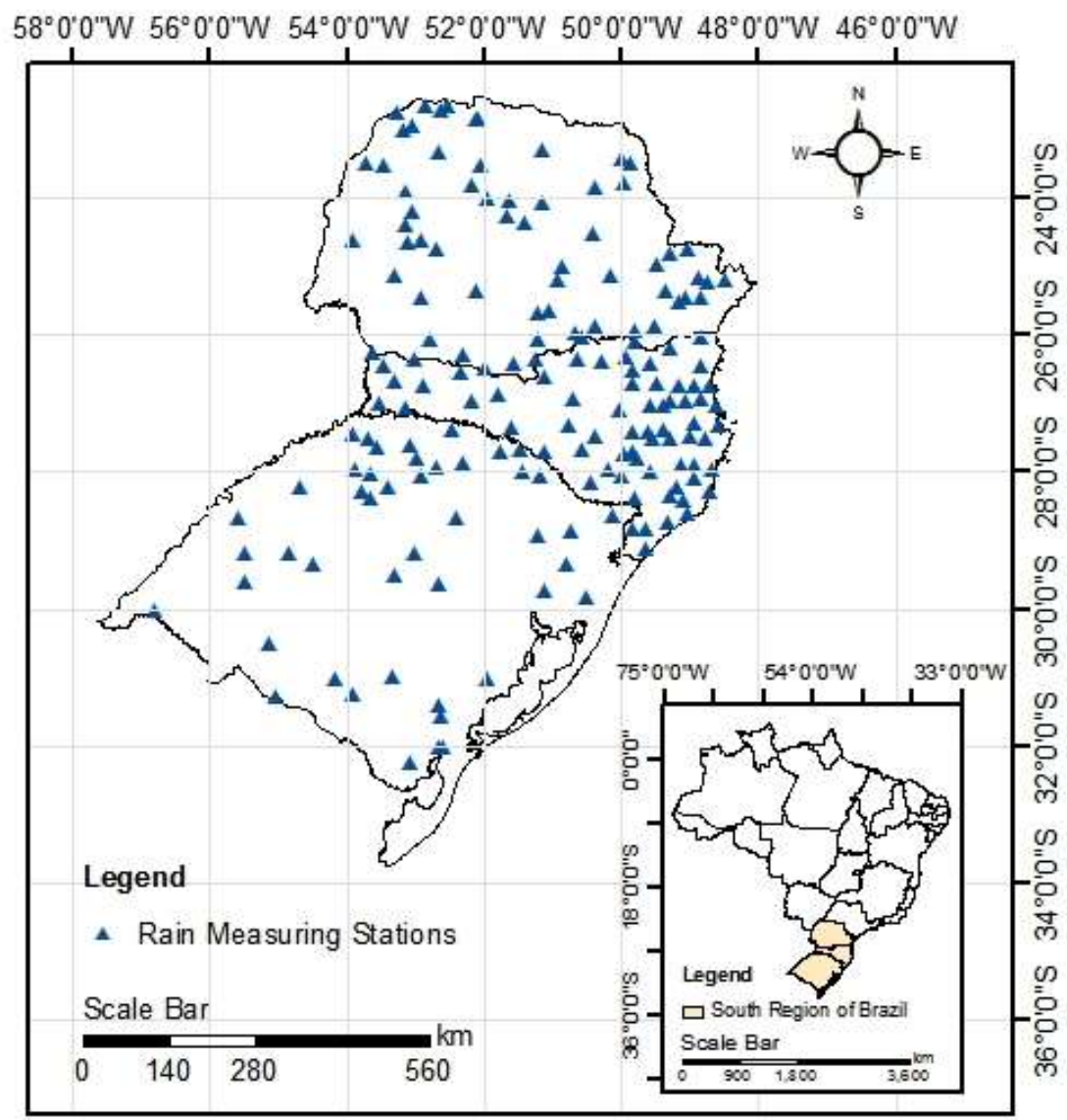

FIGURE 1. Location of selected rain gauge stations. 
Annual MFI values were calculated using [eq. (1)].

$$
M F I=\frac{\sum_{i=1}^{12}\left(p_{i}\right)^{2}}{P}
$$

Where,

MFI is the Modified Fournier Index (mm);

pi is monthly precipitation (mm),

$\mathrm{P}$ is the mean annual precipitation $(\mathrm{mm})$.

The quarterly values were calculated using [eq. (2)]:

$$
\mathrm{MFI}_{\mathrm{t}}=\frac{\sum_{\mathrm{i=1}}^{3}\left(\mathrm{pt}_{\mathrm{i}}\right)^{2}}{\mathrm{P}}
$$

Where,

$\mathrm{MFI}_{\mathrm{t}}$ is the Modified Fournier Index for the trimester (mm),

$\mathrm{Pt}_{\mathrm{i}}$ is rainfall in the trimester $(\mathrm{mm})$.

The Mann-Kendall test was used to evaluate tendencies in MFI series according to [eq. (3)]:

$$
\mathrm{S}=\sum_{\mathrm{j}=1}^{\mathrm{N}-1} \sum_{\mathrm{i}=\mathrm{j}+1}^{\mathrm{N}} \operatorname{sgn}\left(\mathrm{x}_{\mathrm{i}}-\mathrm{X}_{\mathrm{j}}\right)
$$

Where,

$\mathrm{S}$ is Mann-Kendall test statistics.

$$
\operatorname{sgn}(\theta)=\left\{\begin{array}{c}
1 \text { if } \theta>0 \\
0 \text { if } \theta=0 \\
-1 \text { if } \theta<0
\end{array}\right\}
$$

For the independent random variable without significant tendencies, the mean was equal to zero (0), and the variance of $\mathrm{S}$ was calculated using [eq. (5)]:

\begin{tabular}{|c|c|c|c|c|}
\hline \multirow[b]{2}{*}{$\begin{array}{l}\text { Degree of } \\
\text { aggressiveness }\end{array}$} & \multirow[b]{2}{*}{ Rainfall characteristics } & \multicolumn{3}{|c|}{ Classification proposed by } \\
\hline & & $\begin{array}{l}\text { Gomez } \\
(1975)\end{array}$ & $\begin{array}{l}\text { Pizarro et al. } \\
(2008)\end{array}$ & $\begin{array}{c}\text { CEC } \\
(1992)\end{array}$ \\
\hline Very low & Very light, frequent, well-distributed rains & $<140$ & $<100$ & $<60$ \\
\hline Low & Light, frequent, well-distributed rains & $140-210$ & $100-200$ & $60-90$ \\
\hline Intermediate & Moderate, frequent rains with good or regular distribution & $210-280$ & $200-300$ & $90-120$ \\
\hline High & $\begin{array}{l}\text { Heavy rains, frequent or not, with good or poor } \\
\text { distribution }\end{array}$ & $280-350$ & $300-400$ & $120-160$ \\
\hline Very high & $\begin{array}{l}\text { Very heavy rains, frequent or not, with good or poor } \\
\text { distribution }\end{array}$ & $>350$ & $>400$ & $>160$ \\
\hline
\end{tabular}

$$
\operatorname{Var}(\mathrm{S})=\frac{\mathrm{N}(\mathrm{N}-1)(2 \mathrm{~N}+5)-\sum_{\mathrm{t}}^{\mathrm{N}} \mathrm{t}(\mathrm{t}-1)(2 \mathrm{t}+5)}{18}
$$

TABLE 1. Classification of annual rainfall erosivity.

\section{RESULTS AND DISCUSSION}

The percentage of rain gauge stations with significant decreasing trends, significant increasing trends, and no significant trends in rainfall aggressiveness between years was $3.3 \%, 7.7 \%$, and $89.0 \%$, respectively (Table 2). In the state of Rio Grande do Sul, a significant decreasing trend was identified in five stations $(10.2 \%$ of the stations in the state). In contrast, in Paraná and Santa Catarina, excluding one station with a decreasing trend, the other 14 stations presented a significant increasing trend (Figure 2).
Where

$\mathrm{t}$ represents values with the same score.

For the two-tailed test at a level of significance of $\alpha$, Ho is rejected if the standardized Mann-Kendall statistic $\mathrm{Z}$ is smaller than $Z_{\alpha / 2}$ or larger than $Z_{\alpha / 2}$ and follows a normal distribution with a mean of zero and variance of one. $\mathrm{Z}$ was calculated using [eq. (6)]:

$$
Z=\left\{\begin{array}{c}
\frac{S-1}{\sqrt{\operatorname{var}(S)}} \text { if } S>0 \\
0 \text { if } S=0 \\
\frac{S+1}{\sqrt{\operatorname{var}(S)}} \text { if } S<0
\end{array}\right\}
$$

The Mann-Kendall test was performed at a significance level of $5 \%(\alpha=0.05)$. This test is strongly recommended by the World Meteorological Organization (Yue et al., 2002; Huang et al., 2014) to identify trends in historical series of hydrological, climatic, and related data.

Maps of mean quarterly and annual MFI values and MFI classification were generated according to the degree of rainfall aggressiveness. In Europe, the limits were adopted according to ECC (1992). Nonetheless, these limits are low to assess rainfall aggressiveness in tropical climates. The limits presented by Gomez (1975) and Pizzaro et al. (2008) were higher than those proposed by ECC (1992) and are more suitable for the weather conditions of South America (Table 1). Ramirez-Ortiz et al. (2007) analyzed RE in the coffeegrowing zone of Venezuela using the classification proposed by ECC (1992) but observed that MFI values were above $170 \mathrm{~mm}$. For this reason, the values were redistributed in eight classes to identify zones with erosion potential. The classification of Gomez (1975) was used in the present study.
More than $90 \%$ of the stations had no significant trends in RE between seasons. The percentage of significant trends was comparatively higher $(7.2 \%)$ in the summer and lower $(2.8 \%)$ in winter. These significant trends can be attributed to reasons other than climate change, including alterations in station location and natural climate variability.

There were no zones with consistent trends in all the constituent rain gauge stations (Figure 2). Even in regions with a higher concentration of stations with increasing trends, such as in the northwest of Paraná, some stations had no significant trends, and one station had a decreasing trend. 
TABLE 2. Proportion of rain gauge stations according to trends in the Modified Fournier Index.

\begin{tabular}{|c|c|c|c|c|c|c|}
\hline \multirow{2}{*}{ State or region } & \multirow{2}{*}{ Trend } & \multicolumn{5}{|c|}{ Period } \\
\hline & & Annual & Summer & Autumn & Winter & Spring \\
\hline \multirow{3}{*}{ Paraná } & Decrease & 1.4 & 0.0 & 7.1 & 1.4 & 4.3 \\
\hline & Not significant & 84.3 & 85.7 & 90.0 & 95.7 & 91.4 \\
\hline & Increase & 14.3 & 14.3 & 2.9 & 2.9 & 4.3 \\
\hline \multirow{3}{*}{ Santa Catarina } & Decrease & 0.0 & 3.2 & 1.6 & 1.6 & 4.8 \\
\hline & Not significant & 93.5 & 91.9 & 96.8 & 98.4 & 93.5 \\
\hline & Increase & 6.5 & 4.8 & 1.6 & 0.0 & 1.6 \\
\hline \multirow{3}{*}{ Rio Grande do Sul } & Decrease & 10.2 & 4.1 & 2.0 & 2.0 & 0.0 \\
\hline & Not significant & 89.8 & 95.9 & 98.0 & 98.0 & 98.0 \\
\hline & Increase & 0.0 & 0.0 & 0.0 & 0.0 & 2.0 \\
\hline \multirow{3}{*}{ South of Brazil } & Decrease & 3.3 & 2.2 & 3.9 & 1.7 & 3.3 \\
\hline & Not significant & 89.0 & 90.6 & 94.5 & 97.2 & 93.9 \\
\hline & Increase & 7.7 & 7.2 & 1.7 & 1.1 & 2.8 \\
\hline
\end{tabular}

Some studies found significant trends in rainfall series in the south of Brazil (Minuzzi \& Caramori, 2011; Pinheiro et al., 2013; Haylock et al., 2006), whereas other studies found no significant trends (Silva et al., 2015; Denski \& Back, 2015). This apparent discrepancy is in part due to different time periods covered in these data series and different methodologies. Silva et al. (2010) analyzed rainfall time-series across Brazil from 1961 to 2008 and found differentiated and highly regionalized patterns in the increasing and decreasing trends in rainfall. In annual series, the eastern area of the south of Brazil stands out as having significant positive trends from the center of Rio Grande do Sul to Paraná. In contrast, Salviano et al. (2016) analyzed annual rainfall series from 1961 to 2011 in Brazil and observed non-significant trends in more than $70 \%$ of these series and in most months of the year in the south of Brazil.

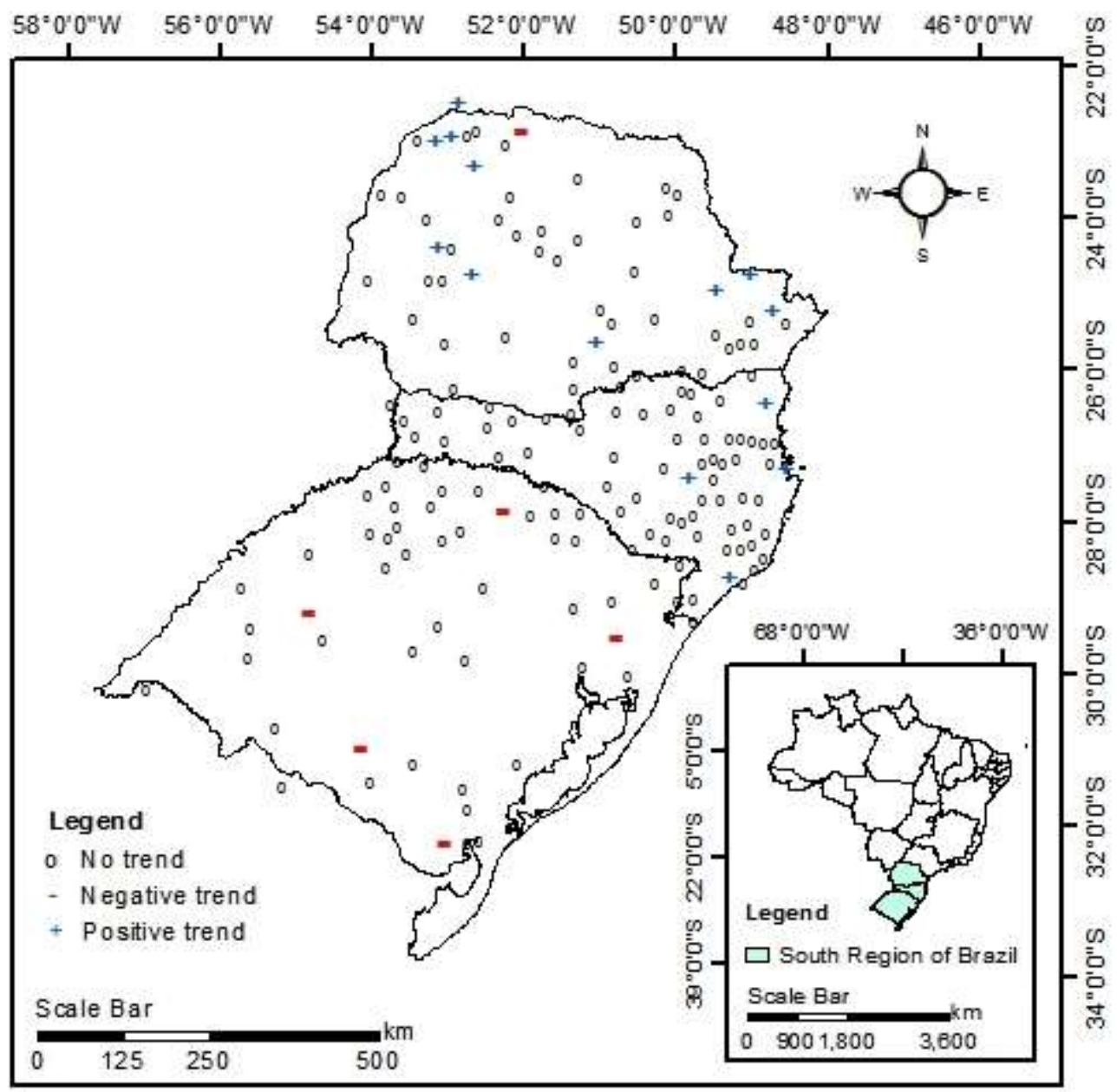

FIGURE 2. Analysis of trends in MFI collected in rain gauge stations distributed across the south of Brazil. 
The variation in MFI was higher in Paraná and Santa Catarina, especially from January to March (Figure 3). Moreover, median MFI was significantly higher in Paraná from November to January and May and significantly higher in Santa Catarina in February and March. In April and from June to October, median MFI was significantly higher in the state of Rio Grande do Sul.

In summer, mean MFI values were comparatively higher in Paraná and Santa Catarina, whereas in autumn, means were comparatively higher in the state of Rio Grande do Sul (Table 3). Mean MFI values were relatively lower in Paraná in winter and comparatively lower in Santa Catarina in spring.

Mean MFI values in the south of Brazil were significantly higher in summer and spring and lower in winter (Figure 4). In Paraná, the variation in the MFI was similar to that observed in the south. In Santa Catarina, there was no significant difference in means between autumn and winter. In Rio Grande do Sul state, means were significantly higher in spring than in summer and autumn and lower in winter.

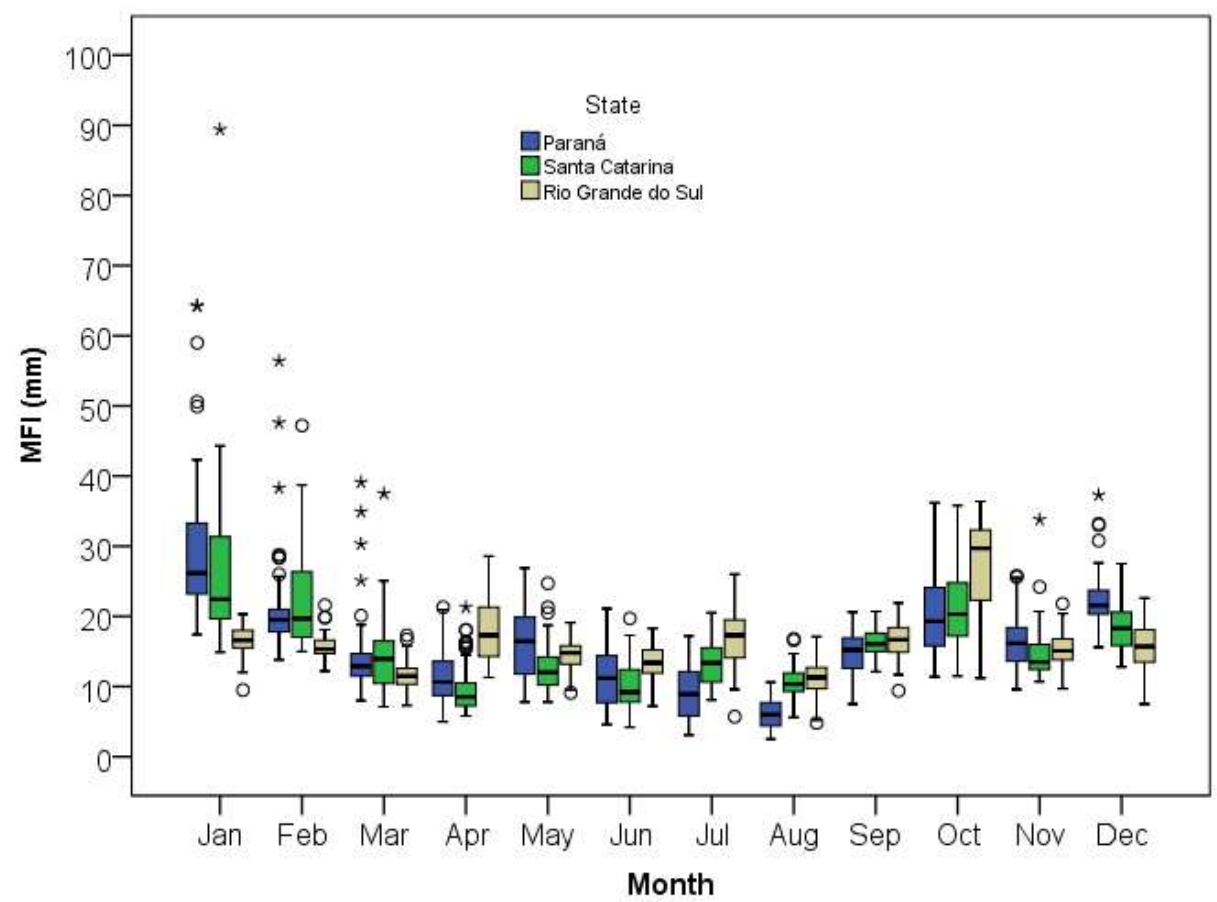

FIGURE 3. Boxplots of the Modified Fournier Index in the south of Brazil.

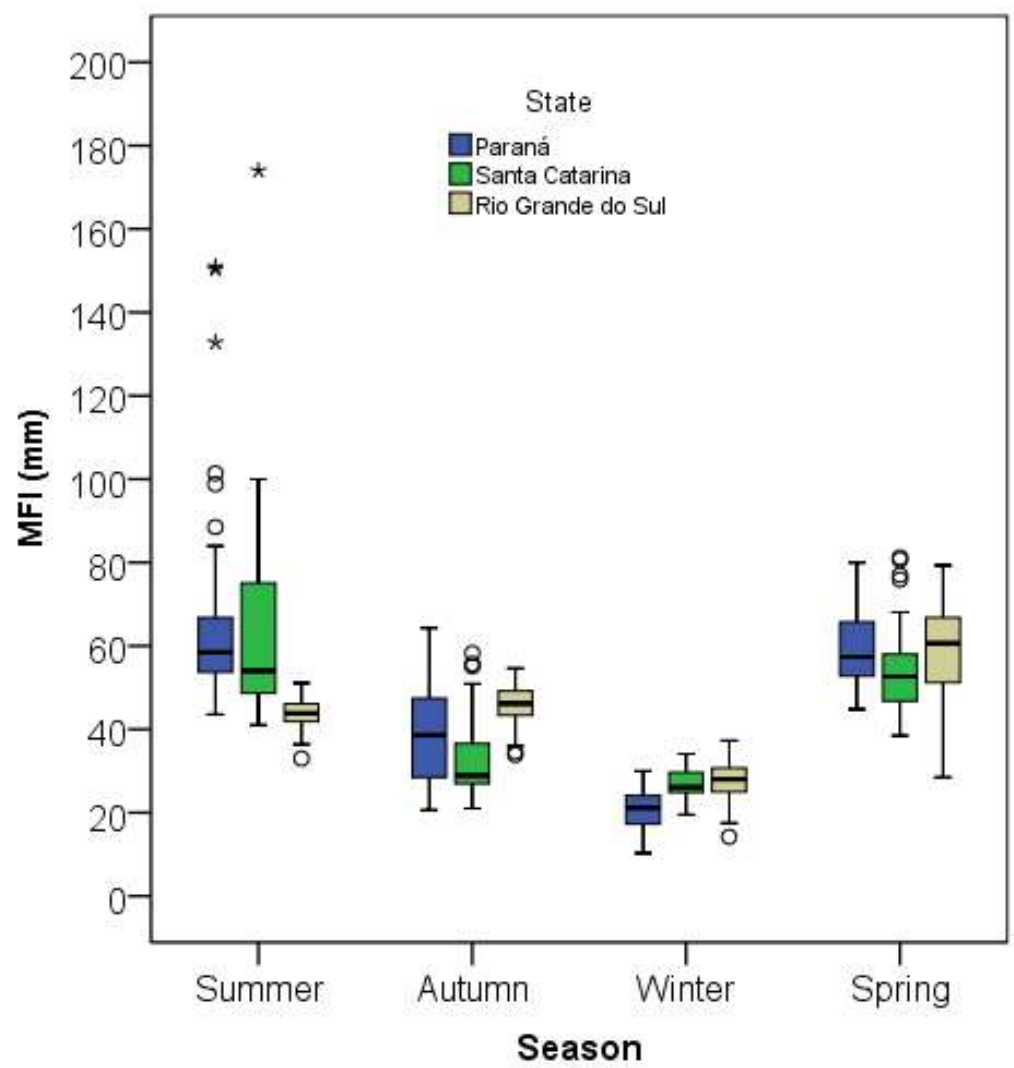

FIGURE 4. Boxplots of the Modified Fournier Index by season in the south of Brazil. 
TABLE 3. Mean values of the Modified Fournier Index in the south of Brazil by state and season of the year.

\begin{tabular}{llllll}
\hline \multirow{2}{*}{ State } & \multicolumn{5}{c}{ Season } \\
\cline { 2 - 6 } & Summer & Autumn & Winter & Spring & Year \\
\hline Paraná & $64.3 \mathrm{aA}$ & $36.3 \mathrm{bB}$ & $20.9 \mathrm{bC}$ & $59.2 \mathrm{aA}$ & $192.8 \mathrm{a}$ \\
Santa Catarina & $62.9 \mathrm{aA}$ & $32.8 \mathrm{cB}$ & $26.6 \mathrm{aB}$ & $54.5 \mathrm{bA}$ & $190.0 \mathrm{a}$ \\
Rio Grande do Sul & $43.7 \mathrm{bB}$ & $45.8 \mathrm{aB}$ & $27.5 \mathrm{aC}$ & $58.0 \mathrm{aA}$ & $192.1 \mathrm{a}$ \\
\hline Southern Brazil & $58.3 \mathrm{~A}$ & $38.8 \mathrm{~B}$ & $24.6 \mathrm{C}$ & $57.3 \mathrm{~A}$ & 191.7 \\
\hline
\end{tabular}

The means followed by the same lowercase letter were not significantly different between the states using the Kruskal-Wallis test at a level of significance of $5 \%$.

The means followed by the same uppercase letter were not significantly different between the rain gauge stations using the Kruskal-Wallis test at a level of significance of $5 \%$.

The seasonal and spatial variation in MFI is due to the formation of rainfall in the south of Brazil. Grimm (2009) has shown that rainfall regimes are highly variable in the south of Brazil, with a marked transition from the north to the south. The north is dominated by a typical monsoon climate, with the beginning of the rainy season in spring and end of the rainy season in early autumn, resulting in large differences in rainfall between summer and autumn. In the south, there is an almost uniform distribution of rainfall throughout the year, with heavier rains in winter. In summer, surface warming and the transfer of moisture to the interior of the continent tend to destabilize the atmosphere, increasing convection and producing heavy rains in the northern states of the south. In summer and transition seasons, mesoscale convective systems are common and responsible for much of the total rainfall. In winter, there is a higher penetration of fronts in Rio Grande do Sul state, causing more rainfall in the southeast of southern Brazil. In the east coast of southern Brazil, particularly in Paraná, there is a significant effect of orography on rainfall. In the southeast of Rio Grande do Sul, maximum rainfall occurs in winter due to the penetration of fronts associated with migratory extratropical cyclones. Summer rains predominate in Paraná and Santa Catarina, and rainfall is higher from December to February or from January to March. Rainfall is higher in spring in the west and in autumn in the north. In the state of Rio Grande do Sul, rainfall is higher from July to September.
In the coast of Santa Catarina, the rugged relief and hills with steep slopes combined with heavy rainfall increase the risk of erosion and landslides (Herrmann, 2007). One of the mechanisms that produce rainfall in Santa Catarina is the displacement of cold fronts and cyclones. Medium to high intensity cyclonic systems are one of the main atmospheric systems affecting rainfall in the southern states of Brazil. Franco et al. (2006) described the effect of sea and land breezes on the atmospheric circulation on the north coast, especially from November to February. Studies on rainfall climatology in Santa Catarina have shown that summer is the rainiest season in coastal areas and Itajaí Valley (Grimm et al., 1998).

Several studies reported the occurrence of orographic precipitation, including floods and landslides along the coast of the south and southeast regions of Brazil (Seluchi \& Chou, 2009; Silva Dias, 2009). The interaction of the effect of orography and cyclones or frontal rains increases rainfall and the risk of floods and landslides. These events cause intense precipitation in summer months in Santa Catarina and Paraná.

The mean annual rainfall varied from 1270 to 2650 $\mathrm{mm}$ (Figure 5) and was higher in the northwest of Rio Grande do Sul, west of Santa Catarina, south-west of Paraná, and in a region between the north coast of Santa Catarina and southeast of Paraná. 

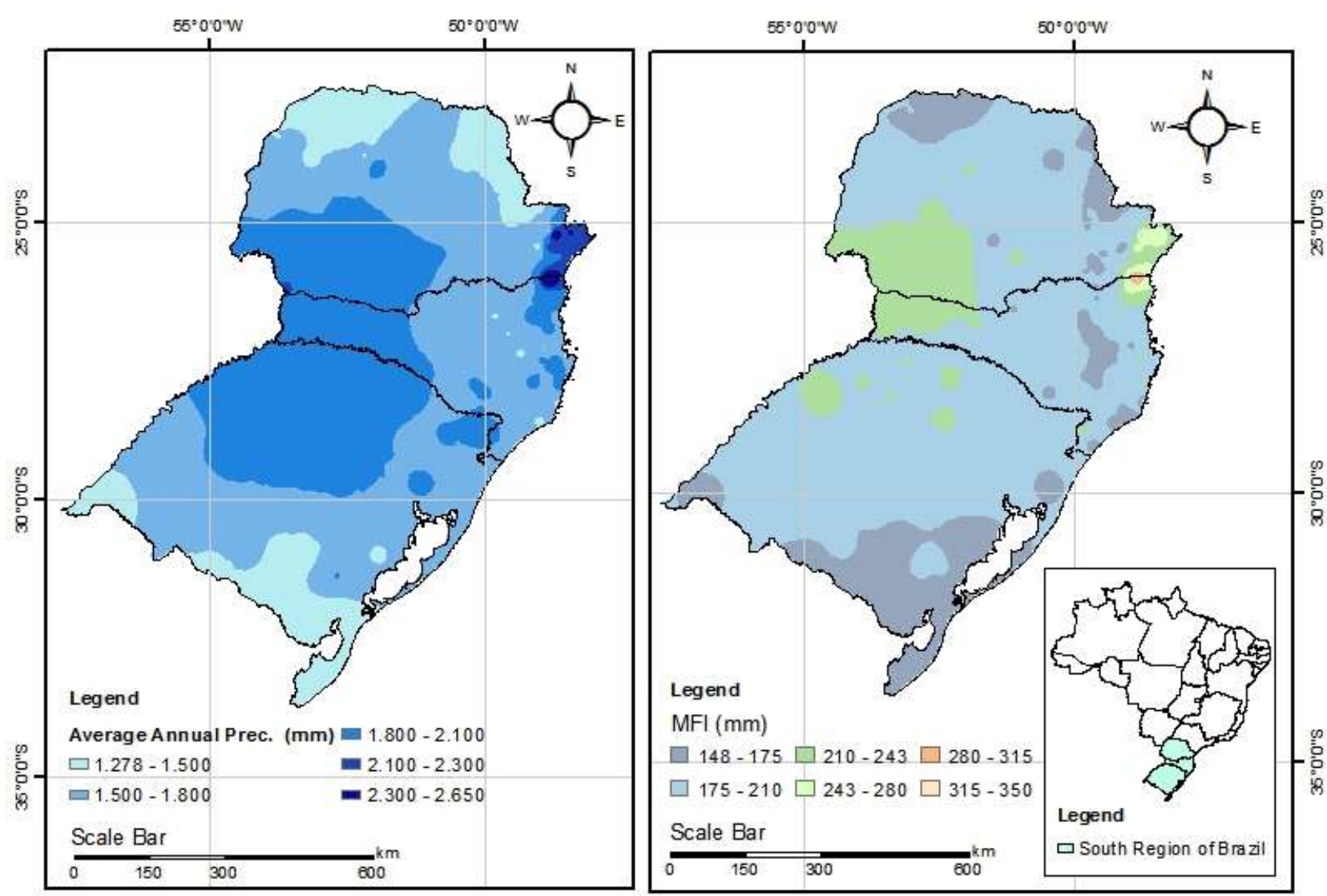

FIGURE 5. Map of annual rainfall (mm) and rainfall erosivity according to the Modified Fournier Index in the south of Brazil.

MFI varied from 148 to 350 , indicating the absence of regions with mild aggressiveness $(\mathrm{MFI}<140)$ in the south (Figure 5). Regions with low aggressiveness $(140<$ MFI < 210) predominated, corresponding to 96.3, 82.8, and $78.2 \%$ of the territory of Rio Grande do Sul, Santa Catarina, and Paraná, respectively (Table 4). In Rio Grande do Sul state, there were a few regions $(3.7 \%$ of the state area) with intermediate aggressiveness in the northwest. In Santa Catarina, these areas were located on the north coast and far west. In Paraná, areas of intermediate RE were found in the southwest and east, close to the border of Santa Catarina. A few locations $(0.4 \%)$ presented high aggressiveness $(280-350 \mathrm{~mm})$ in the north coast of Santa Catarina, close to the border of Paraná; the high aggressiveness was due to precipitation in the municipality of Garuva, where the mean annual rainfall was above $2600 \mathrm{~mm}$ and the mean annual rainfall in January exceeded $400 \mathrm{~mm}$.

TABLE 4. Rainfall aggressiveness in the southern states of Brazil.

\begin{tabular}{lcccc}
\hline Modified Fournier Index $(\mathrm{mm})$ & Paraná & Santa Catarina & Rio Grande do Sul & Southern Brazil \\
\hline$<140$ & 0.0 & 0.0 & 0.0 & 0.0 \\
$140-210$ & 78.2 & 82.8 & 96.3 & 87.6 \\
$210-280$ & 21.7 & 16.8 & 3.7 & 12.3 \\
$280-350$ & 0.1 & 0.4 & 0.0 & 0.1 \\
$>350$ & 0.0 & 0.0 & 0.0 & 0.0 \\
\hline Total & 100.0 & 100.0 & 100.0 & 100.0 \\
\hline
\end{tabular}

In some regions, including the northeast of Santa Catarina (southeast of Paraná) and west of Santa Catarina (southwest of Paraná), higher rainfall aggressiveness coincided with higher annual rainfall. However, in other regions, including the north of Rio Grande do Sul, there was no significant association between these two variables.

The variation in MFI was higher in summer, ranging from 30 to $180 \mathrm{~mm}$. In Rio Grande do Sul state, in the west and plateau of Santa Catarina, and west of Paraná, MFI values were lower than $60 \mathrm{~mm}$ (Figure 6). In the east of Santa Catarina and Paraná, MFI was higher in summer, with values of up to $170 \mathrm{~mm}$ in the north coast of Santa Catarina and southeast of Paraná. In autumn, MFI varied from 20 to $70 \mathrm{~mm}$. MFI was lower in the east and higher in the west of the three states. MFI was higher than $56 \mathrm{~mm}$ in the southwest of Paraná and in a small region in the far west of Santa Catarina. MFI was lower in winter in the north of Paraná and southwest of Rio Grande do Sul, varying from 103 to $40 \mathrm{~mm}$. In spring, MFI ranged from 30 to $80 \mathrm{~mm}$. There was high spatial variability in MFI, with lower values in the eastern zone of the three states and higher values in the western zone, especially in the southwest of Paraná. 


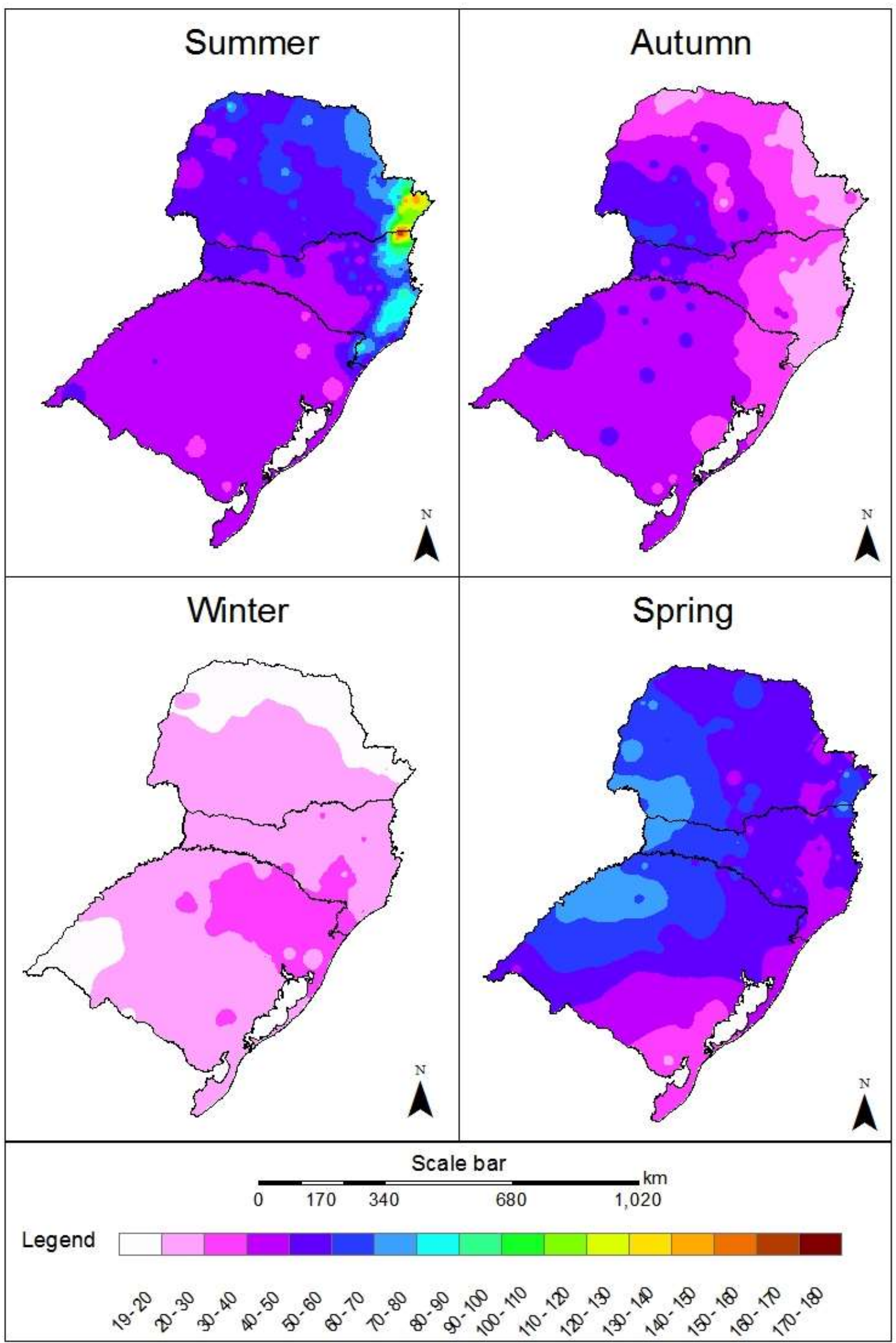

FIGURE 6. Seasonal and spatial variation in rainfall aggressiveness in the south of Brazil. 


\section{CONCLUSIONS}

The results indicated that $89 \%$ of the 181 rain gauge stations that collected annual data series from 1976 to 2015 did not present significant trends in rainfall aggressiveness according to MFI. In addition, 90\% of these stations presented no significant trends between seasons and, therefore, were considered stationary. This result indicates that, although several mechanisms can cause variability in RE and consequently erosion over time, changes in erosivity indexes were not significant in the south of Brazil. Therefore, studies and maps of soil loss potential in southern Brazil developed until 2015 do not need to be updated to account for changes in this variable. The following seasonal and spatial variation in MFI was observed in the three southern states: i) rainfall aggressiveness was higher in Paraná and Santa Catarina in summer and higher in the state of Rio Grande do Sul in autumn; ii) mean rainfall aggressiveness was significantly lower in Paraná in winter and significantly lower in Santa Catarina in spring; iii) RE in southern Brazil was comparatively higher in summer and spring and lower in winter; iv) rainfall aggressiveness in southern Brazil ranged from 148 to $350 \mathrm{~mm} \mathrm{v}$ ) rainfall aggressiveness was comparatively higher in the northern coast of Santa Catarina and southern coast of Paraná, mainly due to summer rains; vii) In autumn, rainfall aggressiveness was higher in the west of these three states. The most likely cause of this difference in RE between the states is the formation of rainfall.

These results may help assess soil erosion in these regions. Nonetheless, the analyzed series indicated that the change in rain aggressiveness is not statistically evident in the series in southern Brazil. Therefore, other factors, including changes in soil use and conservation practices, which are significant contributors to soil loss, may cause erosion.

\section{REFERENCES}

Anache JAA, Wendlad EC, Oliveira PTS, Flanagn DC, Nearing MA (2017) Runoff and soil erosion plot-scale studies under natural rainfall: A meta-analysis of the Brazilian experience. Catena 152:29-39.

CEC - Commission of the European Communities (1992) CORINE soil erosion risk and important land resources in the southern regions of the European Community. Report EUR 13233, Office for Official Publications of the European Communities, Luxembourg.

Davudirad AA, Sadeghi SH, Sadoddin A (2016) The Impact of development plans on hydrological changes in the Shazand Watershed Iran. Land Degradation \& Development 27:1236-1244.

De Luis M, Gonzáles-Hidalgo JC, Longares L A (2010) Is rainfall erosivity increasing in the Mediterranean Iberian Peninsula? Land Degradation \& Development 21:139-144.

Denski APN, Back AJ (2015) Tendência climatológica nos elementos meteorológicos e na evapotranspiração de referência de Urussanga-SC. Revista Brasileira de Climatologia 17:262-274.
Essel P, Glover ET, Yeboah S, Adjei-Kyereme Y, Yawo IND, Nyarku M, Asumadu-Sakyim GS, Gbeddy GK, Agyri YA, Ameho EM, Atule E (2016) Rainfall erosivity index for the Ghana Atomic Energy Commission site. Springerplus 5:465.

FAO - Food and Agriculture Organization of the United Nations (1967) La erosión del suelo por el agua: Algunas medidas para combatirla en las tierras de cultivo. Roma: Organización de Las Naciones Unidas, 207p.

Franco AC, Czarnobai AF, Prudêncio RS (2006) Estudo do regime de ventos para Florianópolis/SC. In: VII Simpósio Brasileiro de Climatologia Geográfica, Rondonópolis, MT. Anais, MT.

Gomez AA (1975) Sistema IUM para determinación del uso y manejo de los suelos de ladera. Cenicafé 26(2):72-86.

Grimm AM (2009) Clima da região Sul do Brasil, In: Cavalcanti IFA. Tempo e clima no Brasil. São Paulo, Oficina Textos, p 259-275.

Grimm AM, Ferraz S, Gomes J (1998) Precipitation Anomalies in Southern Brazil Associated with El Niño and La Niña Events. Journal of Climate 11(11):2863-2880.

Haylock MR, Peterson TC, Alves LM, Ambrizzi T, Anunciação YMT, Baes J, Barros VR, Berlato MA, Bidegain M, Coronel G, Corradi V, Garcia VJ, Grimm AM, Karoly D, Marengo JA, Marino MB, Moncunill DF, Nechet D, Quintana F, Rebello E, Rusticucci M, Santos JL, Trebejo I, Vicent LA (2006) Trends in Total and Extreme South American Rainfall in 1960-2000 and Links with Sea Surface Temperature. Journal of Climate. 19: 1490-1512.

Hazbavi Z, Sadeghi SHR (2016) Potential effects of vinasse as a soil amendment to control runoff and soil loss. Soil 2:71-78.

Herrmann MLP (2007) Atlas de Desastres Naturais de Santa Catarina. Florianópolis, IOESC, 146p.

Huang J, Sun S, Xue Y, Zhang J (2014) Spatial and temporal variability of precipitation indices during 19612010 in Hunan Province, central south China. Theoretical Applied 118:581-595.

Hudson R (1973) Soil conservation. Ithaca, Cornell University Press, 320p.

Jordán A, Bellinfante N (2000) Cartografia de la erosividad de la lluvia estimada a partir de dados pluviométricos mensuales en el Campo de Gibraltar (Cádiz). Edafologia 7(3):83-92.

Lujan DL, Gabriels D (2005) Assessing the rain erosivity and rain distribution in different agro-climatological zones in Venezuela. Sociedade \& Natureza Special Issue:16-29.

Minuzzi RB, Caramori PH (2011) Variabilidade climática sazonal e anual da chuva e veranicos no Estado do Paraná. Revista Ceres 58(5):593-602.

Oliveira PTS, Wendland E, Nearing MA (2012) Rainfall erosivity in Brazil: A review. Catena 100:139-147.

Pinheiro A, Graciano RLG, Severo DL (2013) Tendências das séries temporais de precipitação da Região Sul do Brasil. Revista Brasileira de Meteorologia 28(3):281-290. 
Pizarro R, Cornejo F, González C, Macaya K, Morales C (2008) Análisis del comportamiento y agresividad de las precipitaciones en la zona central de Chile. Tecnología y Ciencias del Agua 23(2):91-109.

Ramirez-Ortiz FA, Hincaapié-Gomez E, SadeghianKhalajabadi S, Perez-Gomez U (2007) Erosividad de las lluvias en la Zona Cafetera Central y Occidental del Departamento de Caldas. Cenicafé 58(1):40-52.

Sadeghi SH, Zabihi M, Vafakhah M Hazbavi Z (2017) Spatiotemporal Mapping of rainfall erosivity index for different return periods in Iran. Nat Hazards 87:35-56.

Salviano MF, Groppo JD, Pellegrino GQ (2016) Análise de tendências em dados de precipitação e temperatura no Brasil. Revista Brasileira de Meteorologia 31(1):64-73.

Seluchi ME, Chou SC (2009) Synoptic patterns associated with landslide events in the Serra do Mar, Brazil.

Theoretical and Applied Climatology 98(1-2):67-77.

Silva Dias MAF (2009) As chuvas de novembro de 2008 em Santa Catarina: um estudo de caso visando à melhoria do monitoramento e da previsão de eventos extremos. INPE, 67p. (Nota Técnica)

Silva FDS, Ferreira DB, Sarmanho GF, Santos LSFC, Fortes LTG, Parente EGP (2010) Tendência de alterações climáticas da precipitação observadas no Brasil de 1961 a 2008 utilizando dados gradeados. In: XII Congresso Brasileiro de Meteorologia. Anais.... Belém: SBMET, 2010. CDRom.

Silva GM, Teixeira-Gandra CFA, Damé RCF, Klumb GB, Veber PM (2015) Tendências de séries de precipitação total mensal para localidades do Rio Grande do Sul. Revista Brasileira de Engenharia e Sustentabilidade 1(2):13-22.
Tafur LE, Moncayo FHO (2010) Erosividad de las lluvias en la Región Centro-Sul del Departamento de Caldas, Colombia. Revista Facultad Nacional de Agronomía. Medellín 63(1):5307-5318.

Tucci CEM (2015) Hidrologia: ciência e aplicação. Porto Alegre, Editora UFRGS/ABRH, 943p.

Vega MB, Flebes J (2007) Dinámica de la erosión de los suelos en áreas rurales de La Habana, Cuba como contribución al desarrollo rural sostenible. In: Seminario Internacional de Cooperación y Desarrollo en Espacios Rurales Iberoamericanos, Sostenibilidad e Indicadores. Almería, España.

Waltrick PC, Machado MAM, Dieckow J, Oliveira D (2015) Estimativa da erosividade de chuvas no estado do Paraná pelo método da pluviometria: Atualização com dados de 1986 a 2008. Revista Brasileira de Ciência do Solo 39(1):256-267.

Wischmeier WH, Smith DD (1960) A universal soil loss estimating equation to guide conservation farm planning. In: International Congress Soil Science. Madison, International Society of Soil Science, Proceedings...

Yue S, Pilon P, Cavadias G (2002) Power of the MannKendall and Spearman's rho tests for detecting monotonic trends in hydrological series. Journal of Hydrology 259:254-271.

Yin S, Xie Y, Liu B, Nearing MA (2015) Rainfall erosivity estimation based on rainfall data collected over arrange of temporal resolutions. Hydrology and Earth System Sciences 19:4113-4126. 